\title{
The physical, insemination, and reproductive quality of honey bee queens (Apis mellifera $\mathrm{L}$. )*
}

\author{
Deborah A. Delaney, Jennifer J. Keller, Joel R. CAREn, David R. TARPY
}

Department of Entomology, Campus Box 7613, North Carolina State University, Raleigh NC 27695-7613, USA

Received 23 October 2009 - Revised 26 January 2010 - Accepted 3 February 2010

\begin{abstract}
Understanding the reproductive potential ("quality") of queens bees can provide valuable insights into factors that influence colony phenotype. We assayed queens from various commercial sources for various measures of potential queen quality, including their physical characters (such as their degree of parasitism), insemination number (stored sperm counts), and effective paternity frequency (number of drone fathers among their offspring). We found significant variation in the physical, insemination, and mating quality of commercially produced queens, and we detected significant correlations within and among these various measures. Overall, the queens were sufficiently inseminated ( $3.99 \pm 1.504$ million sperm) and mated with an appropriate number of drones (effective paternity frequency: $16.0 \pm 9.48$ ). Importantly, very few of the queens were parasitized by tracheal mites and none were found with either Nosema species. These findings suggest possible mechanisms for assessing the potential fitness of honey bee queens without the need for destructive sampling.
\end{abstract}

honey bee queens / reproductive potential / insemination / parasitism / effective mating frequency

\section{INTRODUCTION}

Honey bees are highly eusocial insects, such that they have a highly cooperative system of brood care, overlapping generations, and a strong reproductive division of labor (Wilson, 1971). The latter distinction is manifest in the extreme, where a single reproductive female - the queen - is the sole egg layer within a colony. The queen also passively maintains the social cohesion of the colony by continuously producing a suite of pheromones, which prevents the workers from both raising new queens and developing their ovaries (reviewed in Winston, 1987). As a result, queen bees are the most important individuals within honey bee colonies for both genetic and social reasons. Thus understanding the reproduc-

Corresponding author: D. Tarpy,

david_tarpy@ncsu.edu

Current address: Department of Entomology and Wildlife Biology, University of Delaware, 252 Townsend Hall, Newark, DE 19716, USA.

* Manuscript editor: Klaus Hartfelder tive potential of honey bee queens will provide valuable insights for improving queen quality and overall colony fitness.

There are many measures that can serve as proxies for queen reproductive "quality". The most intuitive perhaps are standard morphological measures of individual adult insects, such as wet or dry weight, thorax width, head width, and wing lengths (Weaver, 1957; Fischer and Maul, 1991; Dedej et al., 1998; Hatch et al., 1999; Gilley et al., 2003; Dodologlu et al., 2004; Kahya et al., 2008), several of which are significantly correlated with queen reproductive success or fecundity (Eckert, 1934; Avetisyan, 1961; Woyke, 1971; Nelson and Gary, 1983). The important glycolipoprotein vitellogenin $\left(V_{g}\right)$ is also a potential indicator of fecundity since it is the yolk precursor associated with egg production (Engels, 1974; Tanaka and Hartfelder, 2004).

Another measure of a queen's quality is the degree to which she is parasitized. While honey bees are hosts to a wide variety of parasites and pathogens (Schmid-Hempel, 1998), 
only a subset tend to infect queen bees. The more notable parasites of queens are tracheal mites Acarapis woodi (Burgett and Kitprasert, 1992; Camazine et al., 1998; Villa and Danka, 2005), the gut protozoan Nosema apis (Webster et al., 2004, 2008) and, presumably, N. ceranae (Higes et al., 2006, 2008). Moreover, queens may be infected with numerous viruses (Chen et al., 2005; Yang and Cox-Foster, 2005), including acute bee paralysis virus (ABPV), chronic bee paralysis virus (CBPV), black queen cell virus (BQCV), deformed wing virus (DWV), Kashmir bee virus (KBV), sacbrood virus (SBV), and Israeli acute paralysis virus (IAPV). While several studies have measured these parasites in queen bees, none has fully investigated how they may impact a queen's reproductive quality.

A queen's quality is not only a function of her own reproductive potential but also how well she is mated. This measure is often gauged by assessing the number of stored sperm in a queen's spermatheca (e.g., Mackensen, 1964; Lodesani et al., 2004; Al-Lawati et al., 2009). A fully mated queen typically stores approximately 5-7 million sperm (Woyke, 1962) that she uses to fertilize eggs over her lifetime. Camazine et al. (1998) estimated the number of sperm in the spermathecae of 325 queens from 13 different commercial queen breeders. They found that $19 \%$ of the queens were "poorly mated" (i.e., they carried fewer than 3 million sperm), as defined by Woyke (1962), a level which they compare to earlier reports of $29 \%$ by Furgala (1962) and $11 \%$ by Jay and Dixon (1984).

The number of stored sperm, however, is not the only measure of a queen's mating success. Queens are highly polyandrous, mating with an average of 12 drones on their mating flight(s) early in life (reviewed by Ruttner, 1956; Tarpy and Nielsen, 2002). It has been shown that polyandry, and the resultant intracolony genetic diversity of the worker force, confers numerous benefits to a colony (reviewed by Palmer and Oldroyd, 2000). First, genetic diversity may increase the behavioral diversity of the worker force (Fuchs and Schade, 1994; Oldroyd et al., 1994; Moritz and Fuchs, 1998; Mattila and Seeley, 2007), such as enabling colonies to exploit different forag- ing environments more efficiently (Lobo and Kerr, 1993; Mattila et al., 2008) or providing a buffer against fluctuations in the environment (Oldroyd et al., 1992; Page et al., 1995; Jones et al., 2004). Second, genetic diversity may reduce the impacts of diploid male production as a consequence of the single-locus sex determination system (Page, 1980; Ratnieks, 1990; Crozier and Pamilo, 1996; Tarpy and Page, 2002). Third, genetic diversity may reduce the prevalence of parasites and pathogens among colony members (Hamilton, 1987; Sherman et al., 1988; Schmid-Hempel, 1998; Palmer and Oldroyd, 2003; Tarpy, 2003; Cremer et al., 2007; Seeley and Tarpy, 2007; Wilson-Rich et al., 2009). Thus determining the number of mates by a queen, and not just the number of sperm, is one final measure of a queen's reproductive quality.

A recent study by vanEngelsdorp et al. (2008) reports the survey results from 305 beekeeping operations in the US, accounting for $13.3 \%$ of managed honey bee colonies nationwide. They found that while starvation, varroa mites, and CCD were significant suspected factors in colony losses $(28 \%, 24 \%$, and $9 \%$, respectively), the primary perceived problem for beekeepers was 'poor queens' $(31 \%)$. Determining the factors that result in low-quality queens is therefore of fundamental importance for improving colony productivity and fitness. In this study, we measured the physical quality (including levels of vitellogenin and parasitism), insemination quality (i.e., stored sperm counts), and mating quality (i.e., number of mates) of 12 honey bee queens from 12 different commercial sources to determine how these measurements are all inter-correlated. This approach will enable us to describe the overall reproductive quality of queen bees and potentially identify any shortcomings that may help improve their reproductive success.

\section{METHODS}

\subsection{Queen ordering}

We ordered naturally open-mated queen honey bees from various commercial queen producers in 
the winter of 2006-2007 for their arrival during the spring of 2007. We selected the queen sources semirandomly to adequately sample different regions of the country (particularly the Southeast and Western regions where queen producers are primarily clustered). Overall, we purchased a total of 12 'Italian' queens from 12 different queen breeding operations. Upon arrival, we introduced two queens from each source into established colonies following standard methods and allowed them to lay. We marked frames where the queens laid eggs and monitored those frames for 21 days. Just prior to brood emergence, we removed the marked frames from each hive and placed them in an incubator set at brood-nest conditions $\left(34{ }^{\circ} \mathrm{C}\right.$ and $\left.\sim 50 \% \mathrm{RH}\right)$. We then sampled the adult offspring from each queen, which were frozen at $-80^{\circ} \mathrm{C}$ for future paternity analysis (see below). The remaining 10 queens from each source were 'banked' (Laidlaw and Page, 1997) in strong colonies until further processing. We also saved the worker "attendants" from each queen shipment at $-80^{\circ} \mathrm{C}$ for later analysis.

\subsection{Dissections}

Once the worker offspring were sampled from a given source (approximately 3 weeks after receiving a given shipment), we weighed all 12 queens (including the two laying queens) to the nearest $0.1 \mathrm{mg}$ on a digital scale after immobilizing them by freezing for $\sim 4 \mathrm{~min}$ at $-20{ }^{\circ} \mathrm{C}$. While immobilized, we also measured their head and thorax widths to the nearest $0.1 \mathrm{~mm}$ using a digital caliper, and we removed each forewing and taped it to a data sheet to subsequently measure wing lengths. We then euthanized each queen in turn by decapitation, pinned her onto a dissection plate, and covered her with RNAlater ${ }^{\circledR}$. We sliced and removed the front quarter of her thorax using a scalpel and placed it on a glass slide. We then viewed the main tracheal trunks under 100X to determine if tracheal mites were present (Shimanuki and Knox, 2000).

We dissected the abdomen of each queen and removed her spermatheca, placing it into a $500 \mu \mathrm{L}$ scintillation vial with $250 \mu \mathrm{L}$ insemination diluent (Harbo and Williams, 1987). We removed each ovary from each queen for separate analysis (data not shown), and we removed the entire mid- and hindguts and placed them into individual $1.5 \mathrm{~mL}$ microcentrifuge tubes with $500 \mu \mathrm{L} \mathrm{dH}_{2} \mathrm{O}$. We placed the remaining eviscerated bodies into separate microcentrifuge tubes with $500 \mu \mathrm{L}$ of fresh
RNAlater ${ }^{\circledR}$. We froze all samples at $-80{ }^{\circ} \mathrm{C}$ for subsequent analysis.

\subsection{Parasites and vitellogenin}

We thawed the mid- and hind gut from each queen and quantified the number of Nosema spores under 400X magnification in a hemacytometer following Cantwell (1970). We then extracted the genomic DNA from each sample following standard laboratory protocols (see also below) and performed Nosema detection PCR following Klee et al. (2006) for which final reaction concentrations were: $1 \times$ PCR buffer; $1.7 \mathrm{mM} \mathrm{MgCl} 2 ; 0.2 \mathrm{mM}$ dNTP's; $0.2 \mu \mathrm{M}$ forward and reverse primers; $0.625 \mathrm{U}$ Taq polymerase; and 5.0 $\mu \mathrm{L}$ DNA template in a final volume of $25 \mu \mathrm{L}$. We ran the reactions for $4 \mathrm{~min}$ at $95{ }^{\circ} \mathrm{C}$, followed by 45 cycles of $1 \mathrm{~min}$ at $95{ }^{\circ} \mathrm{C}$, $1 \mathrm{~min}$ at $48^{\circ} \mathrm{C}$ (Nosema conserved region of $16 \mathrm{~S}$ ), $50{ }^{\circ} \mathrm{C}(\mathrm{N}$. apis $)$, or $55^{\circ} \mathrm{C}(\mathrm{N}$. ceranae $)$, and $1 \mathrm{~min}$ at $72{ }^{\circ} \mathrm{C}$, with a final extension time of $4 \mathrm{~min}$ at $72^{\circ} \mathrm{C}$. We used the primers SSUrRNA-f1/rc1 for detection of Nosema spp., Napis-SSU-Jf1/Jr1 for detection of $N$. apis (Klee et al., 2006), and NC1 (fwd = ccctaagattaacccatgca, rev = ccctccaattaatcacctca) for detection of $N$. ceranae (this study). We resolved the amplified bands on a $1.5 \%$ agarose gel stained with ethidium bromide after electrophoresis for $60 \mathrm{~min}$ at $100 \mathrm{~V}$. Amplicon sizes were $222 \mathrm{bp}$ for the conserved Nosema $16 \mathrm{~S}$ region, 325 bp for $N$. apis, or 328 bp for $N$. ceranae.

We extracted total RNA from each queen's remaining thorax and abdomen using Qiagen RNeasy ${ }^{\circledR}$ kits and synthesized cDNA from the extracted RNA using final reverse transcription reaction concentrations: $1 \times$ Reverse Transcription buffer; $0.5 \mathrm{mM}$ dNTP's; $0.75 \mu \mathrm{L}$ RNaseOUT; $0.012 \mu \mathrm{g} / \mu \mathrm{L}$ random primers; $10 \mathrm{U}$ Superscript III; $5.0 \mu \mathrm{L}$ of RNA in a $10 \mu \mathrm{L}$ reaction. We placed the reactions in a thermocycler and incubated them for $10 \mathrm{~min}$ at $25{ }^{\circ} \mathrm{C}, 50 \mathrm{~min}$ at $42{ }^{\circ} \mathrm{C}$, and $10 \mathrm{~min}$ at $70{ }^{\circ} \mathrm{C}$. We diluted the resultant cDNA's with $60 \mu \mathrm{L} \mathrm{dH} 2 \mathrm{O}$ and added $2.0 \mu \mathrm{L}$ of the dilution to qPCR reactions with final concentrations of: $1 \times$ Sybr Green Master Mix; $1.0 \mu \mathrm{M}$ forward primer; $1.0 \mu \mathrm{M}$ reverse primer in a final volume of $10 \mu \mathrm{L}$. We ran the qRT-PCR reactions on an ABI Prism $7900^{\mathrm{TM}}$ sequence detector, using $\beta$-actin as a control gene, for the viruses ABPV, CBPV, BQCV, DWV, KBV, SBV (Chen et al., 2004), and IAPV (Cox-Foster et al., 2007). We performed these same virus screens on four attendant workers from each 
commercial source to verify the virus' presence in the original operations prior to queen introduction to the banking or laying colonies. We also quantified the relative RNA levels of vitellogenin $\left(V_{g}\right)$ in each queen as in Kocher et al. (2008). We performed all reactions in triplicate and averaged them for final quantification.

\subsection{Sperm}

We thawed the frozen spermathecae from all sampled queens $(n=115)$ and burst them in $1.0 \mathrm{~mL}$ HEPES-buffered saline with $250 \mu \mathrm{L}$ Tween 20 (10\% solution). We removed the spermathecal membrane, tracheal net, and any other debris from each sample and gently mixed the sperm into solution with forceps. Each sample then received $5 \mu \mathrm{L}$ of propidium iodide and was incubated at $36^{\circ} \mathrm{C}$ for 5-10 min (Molecular Probes, LIVE/DEAD ${ }^{\circledR}$ Sperm Viability Kit, L-7011).

Immediately following sperm staining, we filled one chamber of a hemacytometer with $\sim 10 \mu \mathrm{L}$ of solution. We then photographed five nonoverlapping fields of view using a Zeiss Axioskop epifluorescent microscope (Carl Zeiss, Hanover, MD) with a Rodamine filter and a Q Imaging Retiga 1300 camera. We visualized the sperm using Capture ${ }^{\mathrm{TM}}$ software, and we compiled pictures taken at 6-8 depths (vertical planes) to calculate the total number of sperm present in each volume of the hemacytometer field. We then averaged the sperm counts from the five fields of view and corrected for volume and dilution to calculate the total number of sperm found in each queen's spermatheca.

\subsection{Microsatellite analysis}

We extracted the total DNA from the hind leg of individual adult honey bee workers by placing them in $150 \mu \mathrm{L}$ of $10 \%$ Chelex $^{\circledR}$ and $5 \mu \mathrm{L} 0.35 \mathrm{mg} / \mu \mathrm{L}$ proteinase K (Walsh et al., 1991). Each sample was placed in a thermocycler for $1.0 \mathrm{~h}$ at $55^{\circ} \mathrm{C}, 15 \mathrm{~min}$ at $99{ }^{\circ} \mathrm{C}, 1 \mathrm{~min}$ at $37^{\circ} \mathrm{C}$, and $15 \mathrm{~min}$ at $99{ }^{\circ} \mathrm{C}$. We stored the extracted DNA at $-20{ }^{\circ} \mathrm{C}$ for future use, and we analyzed 43-259 workers from each laying queen (with the final sample size depending on initial estimates of queen mating number; see Tarpy and Nielsen, 2002).

We characterized eight variable microsatellite loci for all samples: Am010, Am043, Am052, Am059, Am061, Am098, Am125 (Estoup et al.,
1995; Garnery et al., 1998; Solignac et al., 2003), and Am553 (this study; CGCTGGAAATTGTTCGAGA (fwd) and GGGAGACTTACTGCTTCGA (rev)). We divided the amplification of the eight loci into two multiplex reactions, each using $10 \mu \mathrm{L}$ PCR reactions containing $1 \times$ Promega reaction buffer, 1.5 U Taq polymerase (Promega, Madison WI), $0.3 \mathrm{mM}$ dNTP mixture, 1.0-4.0 $\mu \mathrm{M}$ of florescent dye-labeled primer, $0.001 \mathrm{mg}$ bovine serum albumin, and $1 \mu \mathrm{L}$ of template DNA. The loci in Multiplex 1 were $A m 010, A m 052, A m 553$ and $A m 061$ and had a final concentration of $1.5 \mathrm{mM} \mathrm{MgCl} 2$. The loci in Multiplex 2 were Am059, Am043, Am098 and $A m 125$ and had a final concentration of $1.2 \mathrm{mM}$ $\mathrm{MgCl}_{2}$. All reactions were amplified at $95{ }^{\circ} \mathrm{C}$ for one $7 \mathrm{~min}$ cycle, 30 cycles of $95{ }^{\circ} \mathrm{C}$ for $30 \mathrm{~s}$, $55^{\circ} \mathrm{C}$ (Multiplex 1) or $58^{\circ} \mathrm{C}$ (Multiplex 2) for $30 \mathrm{~s}$, $72{ }^{\circ} \mathrm{C}$ for $30 \mathrm{~s}$, and a final extension at $72{ }^{\circ} \mathrm{C}$ for $60 \mathrm{~min}$. We ran the amplifications using an Applied Biosystems $3730^{\mathrm{TM}}$ automatic sequencer, and we scored the microsatellite fragment sizes using GeneMapper $^{\mathrm{TM}}$ software (Applied Biosystems).

We analyzed the raw microsatellite data using the program COLONY (Wang, 2004) to quantify the number and frequencies of each subfamily (patriline), from which we then calculated the observed mating number $\left(N_{o}\right)$ and the effective paternity frequency $\left(m_{e}\right)$ of each queen as in Tarpy et al. (2004).

\section{RESULTS}

\subsection{Physical quality}

Mean wet weight (WT) for non-laying queens was $184.8 \pm 21.67 \mathrm{mg}$, and their average thorax width (TW) was $4.35 \pm 0.188 \mathrm{~mm}$, head width (HW) $3.62 \pm 0.123 \mathrm{~mm}$, right wing length (RWL) $9.73 \pm 0.240 \mathrm{~mm}$, left wing length (LWL) $9.75 \pm 0.230 \mathrm{~mm}$, and fluctuating asymmetry (FA) $0.09 \pm 0.082 \mathrm{~mm}$ (defined as the absolute value of the difference in rightand left wing lengths). Only TW and HW were normally distributed, so we used Spearman $\rho$ non-parametric correlations to compare all variables. All correlations were positive and statistically significant except for those with FA, which was only significant with HW (Fig. 1). There were significant differences across the various sources for WT (Wilcoxon Rank Sums, $\left.\chi^{2}=38.1, P<0.0001\right)$, TW $\left(\chi^{2}=36.1, P<0.0001\right), \mathrm{HW}\left(\chi^{2}=27.4, P<\right.$ 


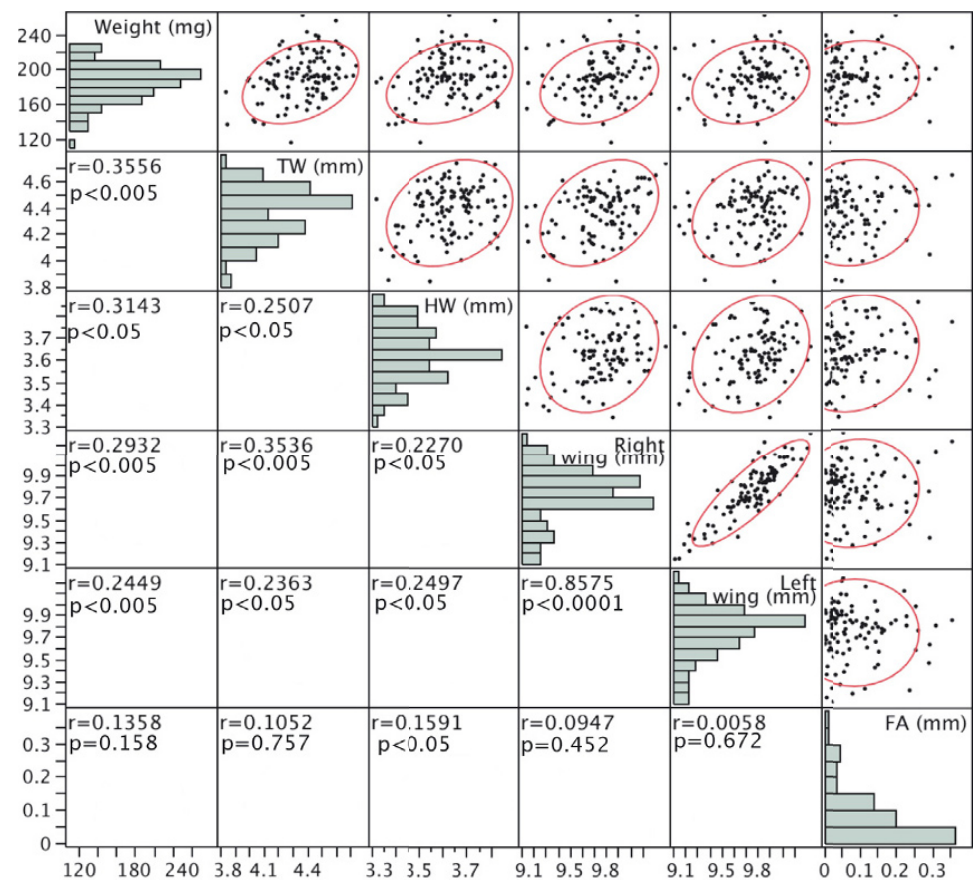

Figure 1. Correlations among the various morphological measures of queens, including wet weight, thorax width (TW), head width (HW), right- and left wing lengths, and fluctuating asymmetry (FA; absolute value of the difference in right- and left wing lengths). All correlations were statistically significant except those with FA.

$0.005)$, and RWL $\left(\chi^{2}=22.6, P<0.05\right)$. We also detected a significant difference in TW between producers in the Southeast compared to those in the West $\left(t_{115}=-2.47, P<0.05\right)$, where Southeastern queens were significantly larger than those produced in the West.

Average $V_{g}$ expression was $24.3 \pm 36.36$ times the level of actin in pre-laying queens, which was significantly higher in laying queens $\left(t_{112}=3.29, P<0.005\right.$; Fig. 2$)$. However, this effect is likely an effect of body size, since $V_{g}$ was significantly logistically correlated with wet weight $\left(r^{2}=0.14, P<0.001\right.$; Fig. 2) and laying queens are heavier because of their active ovaries. As such, when analyzed together, weight was significant $\left(t_{112}=2.71\right.$, $P<0.01)$ whereas laying was not $\left(t_{112}=\right.$ $-0.91, P=0.36)$. There were significant differences across the various queen sources for $V_{g}$ RNA expression $\left(\chi^{2}=55.2, P<0.0001\right)$.

We did not detect any Nosema spores in the digestive tracts of the queens, and all queens

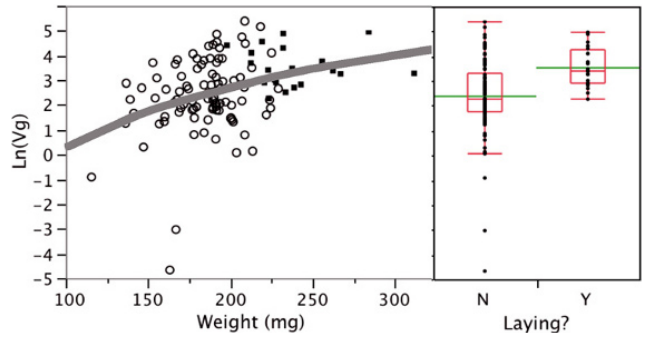

Figure 2. Relative expression levels of vitellogenin $\left(V_{g}\right)$ were significantly greater in laying queens compared to non-laying queens (right). However, this distinction was largely a result of differences in queen wet weight, which was significantly logistically correlated with $V_{g}$ levels.

were negative in their PCR analyses following Klee et al. (2006). Only 3 out of 114 queens $(2.6 \%)$ were parasitized by tracheal mites, and all of those came from the same commercial source. We did, however, detect 


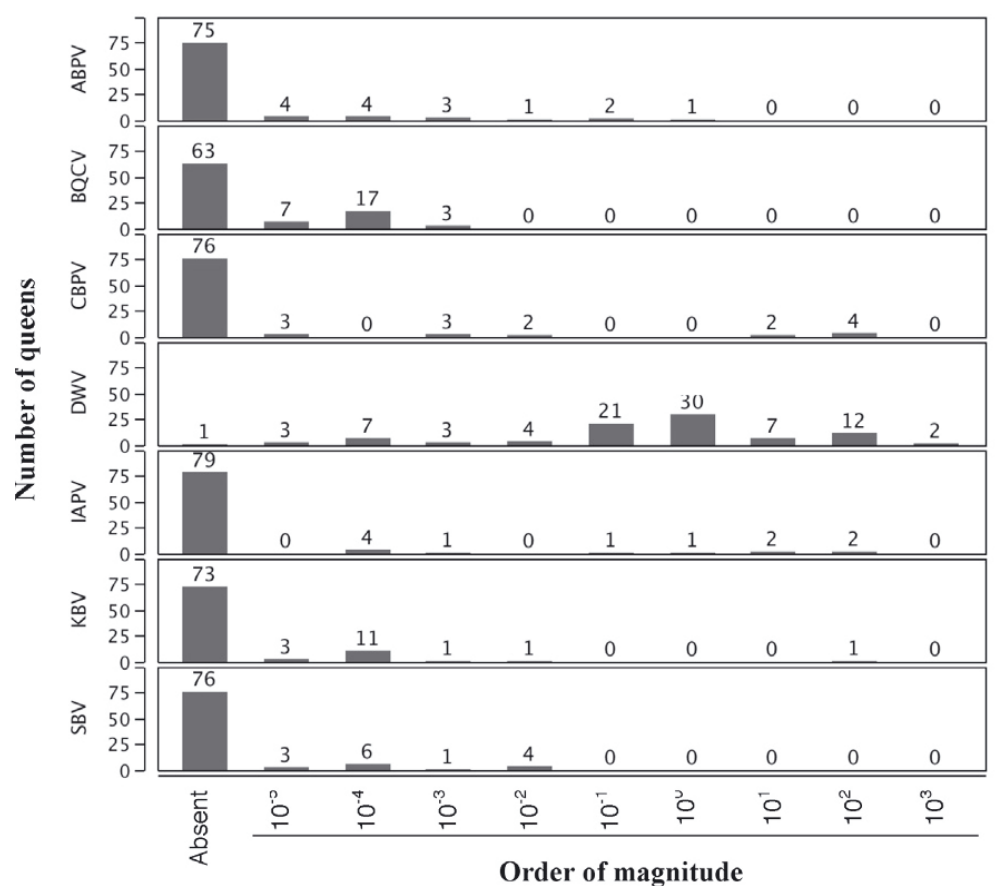

Figure 3. The incidence and prevalence of honey bee viruses among queens. ABPV = acute bee paralysis virus; $\mathrm{BQCV}=$ black queen cell virus; $\mathrm{CBPV}=$ chronic bee paralysis virus; $\mathrm{DWV}=$ deformed wing virus; $\mathrm{IAPV}=$ Israeli acute paralysis virus; $\mathrm{KBV}=\mathrm{Kashmir}$ bee virus; $\mathrm{SBV}=$ sacbrood virus. Virus transcripts were either not detected (Absent) or reported according to their relative order or magnitude with respect to the control gene ( $\beta$-actin).

significant levels of virus among the pre-laying queens (Fig. 3) and detected all seven viruses that were screened. DWV had the highest incidence as well as the highest prevalence (Fig. 3). BQCV was the second most common, but at a much lower incidence. We also detected all seven viruses in the worker attendants from the various source operations, but there were no strong correlations in the incidence or prevalence with viruses detected in the queens (data not shown).

Except for the two possible associations of TW with ABPV $(\rho=0.53, P<0.05)$ and WT with IAPV $(\rho=-0.54, P<0.05)$, we did not detect any significant correlations between any of the queens' physical measures and virus loads (all $P>0.05$ ). However, we did detect a difference between Southeastern and Western sources, where Southeastern queens that were infected with IAPV had significantly higher relative RNA expression lev- els compared to Western queens infected with $\operatorname{IAPV}\left(t_{12}=-3.79, P<0.005\right)$.

\subsection{Insemination quality}

We quantified stored sperm from a total of 115 queens (laying and pre-laying), averaging $3.99 \pm 1.504$ million sperm (range 0.20 9.03 million). There were no differences between pre-laying and laying queens $\left(t_{110}=\right.$ $-0.65, P=0.51)$, thus the brief egg-laying period did not seem to significantly impact sperm counts in the latter group. There were highly significant differences across sources $\left(F_{10,100}=4.24, P<0.0001 ;\right.$ Fig. 4). Overall, $21(18.9 \%)$ queens were 'poorly inseminated' ( $<3$ million stored sperm) and $90(81.1 \%)$ were 'under-inseminated' ( $<5$ million stored sperm).

Weight and $V_{g}$ were not correlated with stored sperm number, even when including 


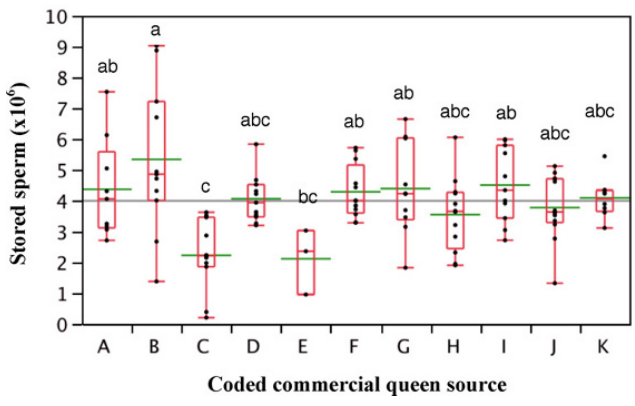

Figure 4. Number of stored sperm across the different commercial operations, which are coded for blindness. There was significant variation in sperm numbers within and among sources, and different letters represent significantly different means according to post-hoc tests at the $\alpha=0.05$ level.

laying as a factor $\left(F_{2,108}=1.45, P=0.24\right.$; $F_{2,108}=0.33, P=0.72$ ). While HW and FA were not correlated with sperm number $\left(r^{2}<0.003, P>0.56\right)$, TW $\left(r^{2}=0.12\right.$, $P<0.0005)$, RWL $\left(r^{2}=0.12, P<0.0005\right)$, and LWL $\left(r^{2}=0.08, P<0.005\right)$ were all positively correlated (Fig. 5).

Only one of the viruses was significantly correlated with sperm counts. We detected a significant negative correlation between lntransformed DWV titers and sperm counts $\left(r^{2}=0.04, P<0.05\right.$; Fig. 5). Nosema and tracheal mites were not compared because of the lack of sufficient positive samples.

\subsection{Mating quality}

A total of 22 queens were genotyped with an average sample size of 116.5 workers per queen (range 43-259). The average observed mating number $\left(N_{o}\right)$ was $25.0 \pm 13.11$ (range $6-50)$, and the average effective paternity frequency $\left(m_{e}\right)$ was $16.0 \pm 9.48$ (range 3.6-38.3). These estimates are within the expected range for the species (Tarpy and Nielsen, 2002). We were not able to compare across operations since only two queens per source were genotyped.

The only physical character that was significantly correlated with mating frequency was TW (Fig. 6), which was positively correlated with both $N_{o}\left(r^{2}=0.25, P<0.05\right)$ and $m_{e}$ $\left(r^{2}=0.25, P<0.05\right)$. There was no effect of any virus on mating number. However, there was a significant logarithmic correlation between effective paternity frequency and stored sperm number $\left(r^{2}=0.20, P<0.05\right.$; Fig. 6), which is consistent with previous findings (Schluns et al., 2005).

\section{DISCUSSION}

We found significant variation in the reproductive quality of honey bee queens. This is evidenced by the wide range in various measures across queens, most of which differed significantly among the different commercial sources. Similar surveys of queen reproductive health have been conducted (e.g., Eckert, 1934; Furgala, 1962; Jay and Dixon, 1984; Camazine et al., 1998; Kahya et al., 2008), but the current study is the most comprehensive in the quantification of physical and mating measurements.

We found that queen weight was positively correlated with $V_{g}$ expression and, consequently, laying queens had significantly higher expression levels of $V_{g}$ versus pre-laying queens. Vitellogenin is a glycolipoprotein produced within the fat bodies, which is taken up by developing oocytes and is stimulated by mating (Kocher et al., 2008, 2010). Our measures of $V_{g}$ may be affected by normalizing expression levels using $\beta$-actin, which may also change as a function of weight or egglaying status. Even still, the increased $V_{g}$ levels in heavier queens is likely a consequence of larger fat bodies triggered by the process of mating (see Kocher et al., 2008). $V_{g}$ also is known to act as an antioxidant and is thought to play a role in queen longevity (Seehuus et al., 2006). As such, $V_{g}$ titers may serve as an effective proxy for queen reproductive quality and health.

Currently, parasites and pathogens are rife among worker honey bees and their presence results in annual losses of honey bee colonies. An emerging gut parasite, Nosema ceranae, and the more familiar N. apis, are of particular interest because studies have shown that these microsporidians can be transferred 

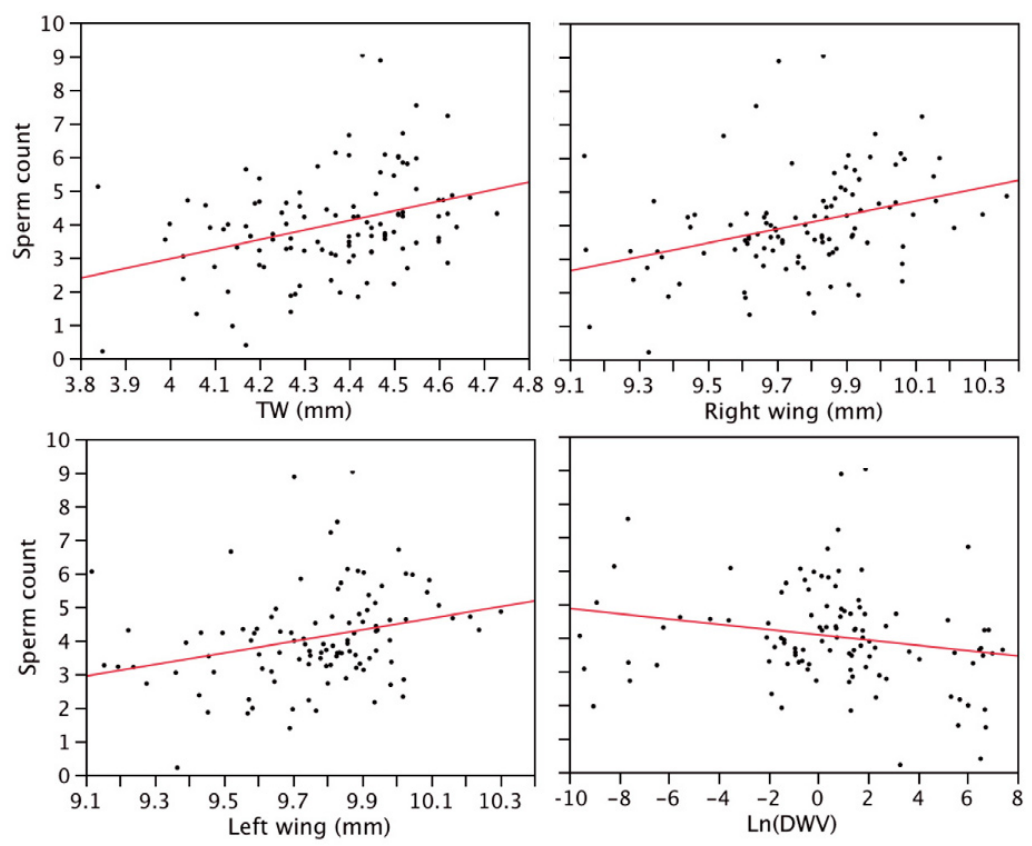

Figure 5. Regression analyses between queen stored sperm counts $\left(\times 10^{6}\right)$ and thorax width (TW), rightand left wing lengths, and ln-transformed relative transcripts of deformed wing virus (DWV). Sperm counts were positively correlated with these measures of body size and negatively correlated with levels of DWV.
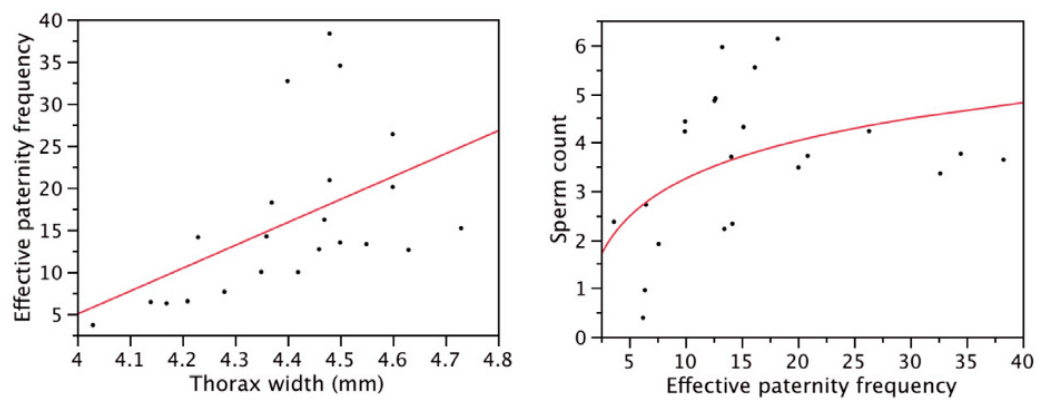

Figure 6. Relationships among thorax width, stored sperm counts $\left(\times 10^{6}\right)$, and effective paternity frequency of queen bees. Thorax width was positively correlated with mating number, and stored sperm count was logistically correlated with increasing mating number.

to the queen via trophallaxis of contaminated food during shipment in queen mailing cages (Webster et al., 2008; Williams et al., 2008). The absence of $N$. apis and N. ceranae, as well as the tracheal mite Acarapis woodi, among the sampled queens in the current study is encouraging, particularly in light of previous studies showing very high infection rates (Furgala, 1962; Jay and Dixon, 1984;
Camazine et al., 1998), and it suggests that commercial queen producers utilize effective management practices regarding the prevention and spread of these parasites.

Various viruses have been implicated as a possible cause of colony collapse disorder (CCD) and a range of other honey bee syndromes (Finley et al., 1996; Evans, 2001; Chen et al., 2004; Cox-Foster et al., 2007). 
The extent of viral loads in US honey bee populations and the development of diagnostic screening tools are subject to ongoing research. However, the effect that these viruses have on the mating health of honey bee queens is not fully understood. While we detected all seven viruses that were screened in the present study, it is difficult to make strong inferences about their effects on queen quality. All of the queens were introduced into novel colony environments (either banking colonies or field hives for egg laying), which were not controlled for levels of virus. Since several of these viruses may be transmitted through trophallaxis or other social contact (Chen et al., 2006), we cannot rule out the possibility that our measures of virus titers were influenced by the queens' subsequent exposure. However, we also screened the worker attendants that arrived with the queen shipments, and we detected similar levels of viruses despite their lack of social exposure. Moreover, the only statistically significant effect of virus prevalence on queen mating was DWV negatively correlating with stored sperm counts. It is possible that there are similar trends among other viruses that could not be detected in the present study; relative to DWV, the remaining six screened viruses have very low incidence among queens, thus with larger sample sizes of infected queens there may be similar negative consequences of other viruses. With these caveats in mind, our observation that queens from producers in the Southeast had higher IAPV titers compared to those in the West suggests possible differences in the virulence of introduced strains (see Palacios et al., 2008), which warrants additional study. There is also an intriguing possibility that DWV may affect sperm production by drones, the ability of queens to adequately store sperm, or both, but more empirical work is needed to elucidate such effects.

The average actual paternity and effective paternity frequency were within the expected range for Apis mellifera L. (Tarpy and Nielsen, 2002), meaning that these commercially produced queens mated with an adequate number of drones. This strongly negates the hypothesis that queen failure in managed honey bee colonies (vanEngelsdorp et al., 2008) is a re- sult of inadequate mating number. However, since only two queens in each of the 12 sources were assayed for paternity frequency in the current study, it would be helpful to ascertain a more thorough diagnosis of queen mating number particularly as it relates to different management practices in commercial queen producers. In doing so, it would also be of interest to quantify the relatedness of the drones mating with queens to further assess genetic diversity within resultant colonies.

Thorax width was positively correlated with both stored sperm number and mating frequency, which suggests that queens with larger thoraces are predisposed to mate with a greater number of drones. One possible explanation is that a larger thorax presumably indicates larger flight muscles, which may enable queens to fly for longer durations on their mating flights and therefore mate with more males. This possibility seemingly contradicts Tarpy and Page (2000), who showed no affect of flight duration on mating number or stored sperm counts, as well as Koeniger and Koeniger (2007) and Hayworth et al. (2009), who more recently found negative correlations of sperm number with flight duration. However, as each study pointed out, any relationship between time-inflight and mating frequency is inherently affected by numerous confounding factors, including season, location, mate availability, and queen decision-making, all of which may obfuscate these relationships and make direct comparisons across different experimental designs difficult. Another, more-direct possibility is that thorax width is a good proxy for the volume of the spermatheca, which would enable larger queens to simply store a greater number of sperm (see Woyke, 1971; Hatch et al., 1999). Unfortunately, none of the above studies nor the current study quantified spermatheca volume, thus it is unclear as to the cause versus effect of queen size on queen mating frequency.

The insemination quality of the queens was significantly different across the various commercial sources, which could be due to many factors. Abiotic factors, such as weather and geographic location, could affect the insemination quality of the queens simply because of the inherent variation in 
local mating environments (e.g., Lensky and Demter, 1985; da Silva et al., 1995). Differing weather conditions during mating flights and overall differing climates at the various drone congregation areas could result in variation in insemination quality (see Koeniger et al., 2005). Biotic factors, such as differences in drone availability, density, and sperm loads among males, could also create significant variation among queens (Haberl and Tautz, 1999; Schluns et al., 2003). Management practices may also significantly affect the overall quality of queens across sources, as different genetic stocks (see Tarpy and Nielsen, 2002), chemical treatments (Haarmann et al., 2002; Pettis et al., 2004), and hive environments (Woyke, 1983; da Silva et al., 1995) are all significant factors in the reproductive biology of queens.

In conclusion, there is significant variation in the physical, insemination, and mating quality of commercially produced queens in the United States. Correlations within and among queen size and insemination quality were observed, suggesting a possible mechanism for assessing the potential fitness of commercially produced honey bee queens without the need for destructive sampling. Future work should focus on how queen and mating quality translates to colony productivity and health, which will enable us to compare queens across differing management practices and elucidate subtle relationships among measures of queen potential fitness.

\section{ACKNOWLEDGEMENTS}

We would like to thank John Harman, Winnie Lee, Flora Lee, Mithun Patel, and Matt Mayer for their help in DNA extractions and PCR analyses. A special thanks goes to Laura Mathies for use of her fluorescent microscope for the sperm analyses. This study was supported by the National Research Initiative of the USDA Cooperative State Research, Education and Extension Service, grant number 2007-02281, as well as by grants from the North Carolina Department of Agriculture and Consumer Services and the California State Beekeepers Association.
La qualité physique et reproductive, et celle de l'insémination, chez les reines d'abeilles (Apis mellifera L.).

reine / abeille / potentiel reproductif / parasitisme / insémination / fréquence d'accouplement effectif

Zusammenfassung - Die physische und reproduktive Qualität sowie der Besamungsgrad von Königinnen der Honigbiene (Apis mellifera L.). Das Verständnis des Reproduktionspotentials von Honigbienen-Königinnen kann wertvolle Einsichten hinsichtlich der Verbesserung der GesamtKolonie-Fitness geben. Dabei können verschiedene Parameter zur Abschätzung der Reproduktionsqualität von Königinnen herangezogen werden. Die intuitivsten sind standardisierte morphologische MaBe, wie Lebend- oder Trockengewicht, Thoraxbreite, Kopfbreite und Flügellänge. Viele dieser Maße erwiesen sich als signifikant mit dem Reproduktionserfolg und der Fekundität korreliert. Das Glykoprotein Vitellogenin $\left(V_{g}\right)$ ist ebenfalls ein wichtiger Indikator der Fekundität, da es als Dotterpoteinvorläufer direkt mit der Eiproduktion verknüpft ist. Ein weiteres Maß für die Königinnenqualität ist auch ihr Parasitierungsgrad, z.B. durch Tracheenmilben, den Darm-Protozoen Nosema apis und N. ceranae, sowie verschiedenen Bienenviren.

Die Qualität einer Königin ist nicht nur eine Funktion ihres Reproduktionspotentials, sondern auch wie gut sie verpaart ist, ein Parameter, der oft anhand der in der Spermatheka vorhandenen Spermienzahl abgeschätzt wird. Er kann aber auch anhand der Genotypisierung der Nachkommen der Königin quantifiziert werden, wobei die Zahl der Paarungen und die effektive Vaterschaftsfrequenz bestimmt werden können.

Im Winter 2007 bestellten wir natürlich verpaarte Könginnen bei verschiedenen kommerziellen Züchtern, die im Frühjahr 2008 geliefert wurden, genauer gesagt waren dies 12 "italienische" Königinnen von 12 verschieden Züchtern. Bei diesen Königinnen bestimmten wir die verschiedenen morphometrischen Standardmaße und quantifizierten den jeweiligen Befallsgrad durch Tracheenmilben, den zwei Nosema-Arten und sieben verschiedenen Bienenviren. Wir präparierten auch die Spermatheka jeder Königin und bestimmten die Spermienzahl mittels Fluoreszenzmikroskopie. Als letztes wurde für jeweils zwei Königinnen der verschiedenen Zuchtlinien die Arbeiterinnen-Nachkommenschaft mittels Mikrosatelliten-PCR genotypisiert, um die effektive Paarungsfrequenz dieser Königinnen bestimmen zu können.

Honigbienen-Königinnen / Reproduktionspotential / Besamung / Parasitierung / effektive Paarungsfrequenz 


\section{REFERENCES}

Al-Lawati H., Kamp G., Bienefeld K. (2009) Characteristics of the spermathecal contents of old and young honeybee queens, J. Insect Physiol. 55, 116-121.

Avetisyan G.A. (1961) The relation between interior and exterior characteristics of the queen and fertility and productivity of the bee colony, XVIII International Beekeeping Congress, pp. 44-53.

Burgett M., Kitprasert C. (1992) Tracheal mite infestation of queen honey-bees, J. Apic. Res. 31, 110111.

Camazine S., Çakmak I., Cramp K., Finley J., Fisher J., Frazier M., Rozo A. (1998) How healthy are commercially-produced US honey bee queens? Am. Bee J. 138, 677-680.

Cantwell G.E. (1970) Standard methods for counting nosema spores, Am. Bee J. 119, 222-223.

Chen Y.P., Pettis J.S., Collins A., Feldlaufer M.F. (2006) Prevalence and transmission of honeybee viruses, Appl. Environ. Microbiol. 72, 606-611.

Chen Y.P., Pettis J.S., Feldlaufer M.F. (2005) Detection of multiple viruses in queens of the honey bee Apis mellifera L, J. Invertebr. Pathol. 90, 118-121.

Chen Y.P., Zhao Y., Hammond J., Hsu H.T., Evans J., Feldlaufer M. (2004) Multiple virus infections in the honey bee and genome divergence of honey bee viruses, J. Invertebr. Pathol. 87, 84-93.

Cox-Foster D.L., Conlan S., Holmes E.C., Palacios G., Evans J.D., Moran N.A., Quan P.L., Briese T., Hornig M., Geiser D.M., Martinson V.,vanEngelsdorp D., Kalkstein A.L., Drysdale A., Hui J., Zhai J.H., Cui L.W., Hutchison S.K., Simons J.F., Egholm M., Pettis J.S., Lipkin W.I. (2007) A metagenomic survey of microbes in honey bee colony collapse disorder, Science 318 , 283-287.

Cremer S., Armitage S.A.O., Schmid-Hempel P. (2007) Social immunity, Curr. Biol. 17, R693R702.

Crozier R.H., Pamilo P. (1996) Evolution of Social Insect Colonies: Sex Allocation and Kin Selection, Oxford University Press, New York.

da Silva E.C.A., Silva R.M.B.D., Chaud-Netto J., Moreti A.C.C.C., Otsuk I.P. (1995) Influence of management and environmental factors on mating success of Africanized queen honey bees, J. Apic. Res. 34, 169-175.

Dedej S., Hartfelder K., Aumeier P., Rosenkranz P., Engels W. (1998) Caste determination is a sequential process: effect of larval age at grafting on ovariole number, hind leg size and cephalic volatiles in the honey bee (Apis mellifera carnica), J. Apic. Res. 37, 183-190.

Dodologlu A., Emsen B., Gene F. (2004) Comparison of some characteristics of queen honey bees (Apis mellifera L.) reared by using Doolittle method and natural queen cells, J. Appl. Anim. Res. 26, 113 115.

Eckert J.E. (1934) Studies in the number of ovarioles in queen honeybees in relation to body size, J. Econ. Entomol. 27, 629-635.

Engels W. (1974) Occurrence and significance of vitellogenins in female castes of social hymenoptera, Am. Zool. 14, 1229-1237.

Estoup A., Garnery L., Solignac M., Cornuet J.-M. (1995) Microsatellite variation in honey bee (Apis mellifera L.) populations: hierarchical genetic structure and test of the infinite allele and stepwise mutation models, Genetics 140, 679695.

Evans J.D. (2001) Genetic evidence for coinfection of honey bees by acute bee paralysis and Kashmir bee viruses, J. Invertebr. Pathol. 78, 189-193.

Finley J., Camazine S., Frazier M. (1996) The epidemic of honey bee colony losses during the 19951996 season, Am. Bee J. 136, 805-808.

Fischer F., Maul V. (1991) Untersuchungen zu aufzuchtbedingten königinnenmerkmalen, Apidologie 22, 444-446.

Fuchs S., Schade V. (1994) Lower performance in honeybee colonies of uniform paternity, Apidologie 25, 155-168.

Furgala B. (1962) Effect of Intensity of nosema inoculum on queen supersedure in honey bee, Apis mellifera Linnaeus, J. Insect Pathol. 4, 429.

Garnery L., Franck P., Baudry E., Vautrin D., Cornuet J.-M., Solignac M. (1998) Genetic diversity of the west European honey bee (Apis mellifera mellifera and $A$. m. iberica). II. Microsatellite loci, Genet. Sel. Evol. 30, S49-S74.

Gilley D.C., Tarpy D.R., Land B.B. (2003) The effect of queen quality on the interactions of workers and dueling queen honey bees (Apis mellifera L.), Behav. Ecol. Sociobiol. 55, 190-196.

Haarmann T., Spivak M., Weaver D., Weaver B., Glenn T. (2002) Effects of fluvalinate and coumaphos on queen honey bees (Hymenoptera: Apidae) in two commercial queen rearing operations, J. Econ. Entomol. 95, 28-35.

Haberl M., Tautz D. (1999) Paternity and maternity frequencies in Apis mellifera sicula, Insectes Soc. 46, 137-145.

Hamilton W.D. (1987) Kinship, recognition, disease, and intelligence: constraints of social evolution, in: Kikkawa J. (Ed.), Animal Societies: Theory and Facts, Japanese Scientific Society Press, Tokyo, pp. 81-102.

Harbo J.R., Williams J.L. (1987) Effect of abovefreezing temperatures on temporary storage of honeybee spermatozoa, J. Apic. Res. 26, 53-55.

Hatch S., Tarpy D.R., Fletcher D.J.C. (1999) Worker regulation of emergency queen rearing in honey 
bee colonies and the resultant variation in queen quality, Insectes Soc. 46, 372-377.

Hayworth M.K., Johnson N.G., Wilhelm M.E., Gove R.P., Metheny J.D., Rueppell O. (2009) Added weights lead to reduced flight behavior and mating success in polyandrous honey bee queens (Apis mellifera), Ethology 115, 698-706.

Higes M., Martin R., Meana A. (2006) Nosema ceranae, a new microsporidian parasite in honeybees in Europe, J. Invertebr. Pathol. 92, 93-95.

Higes M., Martin-Hernandez R., Botias C., Bailon E.G., Gonzalez-Porto A.V., Barrios L., del Nozal M.J., Bernal J.L., Jimenez J.J., Palencia P.G., Meana A. (2008) How natural infection by Nosema ceranae causes honeybee colony collapse, Environ. Microbiol. 10, 2659-2669.

Jay S.C., Dixon D. (1984) Infertile and nosemainfected honeybees shipped to western Canada, J. Apic. Res. 23, 40-44.

Jones J.C., Myerscough M.R., Graham S., Oldroyd B.P. (2004) Honey bee nest thermoregulation: diversity promotes stability, Science $305,402-404$.

Kahya Y., Gencer H.V., Woyke J. (2008) Weight at emergence of honey bee (Apis mellifera caucasica) queens and its effect on live weights at the pre and post mating periods, J. Apic. Res. 47, 118 125.

Klee J., Tay W.T., Paxton R.J. (2006) Specific and sensitive detection of Nosema bombi (Microsporidia: Nosematidae) in bumble bees (Bombus spp.; Hymenoptera: Apidae) by PCR of partial rRNA gene sequences, J. Invertebr. Pathol. 91, 98-104.

Kocher S.D., Richard F.J., Tarpy D.R., Grozinger C.M. (2008) Genomic analysis of post-mating changes in the honey bee queen (Apis mellifera), BMC Genomics 9, 32 .

Kocher S.D., Tarpy D.R., Grozinger C.M. (2010) The effects of mating and instrumental insemination on honey bee flight behavior and gene expression, Insect Mol. Biol. 19, 153-162.

Koeniger N., Koeniger G. (2007) Mating flight duration of Apis mellifera queens: As short as possible, as long as necessary, Apidologie 38, 606-611.

Koeniger N., Koeniger G., Pechhacker H. (2005) The nearer the better? Drones (Apis mellifera) prefer nearer drone congregation areas, Insectes Soc. 52, 31-35.

Laidlaw H.H. Jr., Page R.E. Jr. (1997) Queen Rearing and Bee Breeding, Wicwas, Cheshire, CT.

Lensky Y., Demter M. (1985) Mating flights of the queen honeybee (Apis mellifera) in a subtropical climate, Comp. Biochem. Physiol. 81, 229-241.

Lobo J.A., Kerr W.E. (1993) Estimation of the number of matings in Apis mellifera: Extensions of the model and comparison of different estimates, Ethol. Ecol. Evol. 5, 337-345.

Lodesani M., Balduzzi D., Galli A. (2004) A study on spermatozoa viability over time in honey bee (Apis mellifera ligustica) queen spermathecae, J. Apic. Res. 43, 27-28.

Mackensen O. (1964) Relation of semen volume to success in artificial insemination of queen honey bees, J. Econ. Entomol. 57, 581-583.

Mattila H.R., Seeley T.D. (2007) Genetic diversity in honey bee colonies enhances productivity and fitness, Science 317, 362-364.

Mattila H.R., Burke K.M., Seeley T.D. (2008) Genetic diversity within honeybee colonies increases signal production by waggle-dancing foragers, Proc. R. Soc. Lond. B 275, 809-816.

Moritz R.F.A., Fuchs S. (1998) Organization of honeybee colonies: characteristics and consequences of a superorganism concept, Apidologie 29, 7-21.

Nelson D.L., Gary N.E. (1983) Honey productivity of honey bee Apis-mellifera colonies in relation to body weight attractiveness and fecundity of the queen, J. Apic. Res. 22, 209-213.

Oldroyd B.P., Rinderer T.E., Buco S.M. (1992) Intracolonial foraging specialism by honey bees (Apis mellifera) (Hymenoptera: Apidae), Behav. Ecol. Sociobiol. 30, 291-295.

Oldroyd B.P., Rinderer T.E., Schwenke J.R., Buco S.M. (1994) Subfamily recognition and task specialisation in honey bees (Apis mellifera L.) (Hymenoptera: Apidae), Behav. Ecol. Sociobiol. 34, 169-173.

Page R.E. Jr. (1980) The evolution of multiple mating behavior by honey bee queens (Apis mellifera), Genetics 96, 263-273.

Page R.E. Jr., Robinson G.E., Fondrk M.K., Nasr M.E. (1995) Effects of worker genotypic diversity on honey bee colony development and behavior (Apis mellifera L.), Behav. Ecol. Sociobiol. 36, $387-$ 396.

Palacios G., Hui J., Quan P.L., Kalkstein A., Honkavuori K.S., Bussetti A.V., Conlan S., Evans J., Chen Y.P., vanEngelsdorp D., Efrat H., Pettis J., Cox-Foster D., Holmes E.C., Briese T., Lipkin W.I. (2008) Genetic analysis of Israel acute paralysis virus: distinct clusters are circulating in the United States, J. Virol. 82, 6209-6217.

Palmer K.A., Oldroyd B.P. (2000) Evolution of multiple mating in the genus Apis, Apidologie 31, 235248.

Palmer K.A., Oldroyd B.P. (2003) Evidence for intra-colonial genetic variance in resistance to American foulbrood of honey bees (Apis mellifera): further support for the parasite/pathogen hypothesis for the evolution of polyandry, Nat. Wiss. 90, 265-268.

Pettis J.S., Collins A.M., Wilbanks R., Feldlaufer M.F. (2004) Effects of coumaphos on queen rearing in the honey bee, Apis mellifera, Apidologie 35, 605610.

Ratnieks F.L.W. (1990) The evolution of polyandry by queens in social Hymenoptera: the significance of 
the timing of removal of diploid males, Behav. Ecol. Sociobiol. 26, 343-348.

Ruttner F. (1956) The mating of the honeybee, Bee World 37, 3-15.

Schlüns H., Moritz R.F.A., Neumann P., Kryger P., Koeniger G. (2005) Multiple nuptial flights, sperm transfer and the evolution of extreme polyandry in honeybee queens, Anim. Behav. 70, 125-131.

Schlüns H., Schlüns E.A., van Praagh J., Moritz R.F.A. (2003) Sperm numbers in drone honeybees (Apis mellifera) depend on body size, Apidologie 34, 577-584.

Schmid-Hempel P. (1998) Parasites in Social Insects, Princeton University Press, Princeton, NJ.

Seehuus S.C., Norberg K., Gimsa U., Krekling T., Amdam G.V. (2006) Reproductive protein protects functionally sterile honey bee workers from oxidative stress, Proc. Natl. Acad. Sci. USA 103, 962-967.

Seeley T.D., Tarpy D.R. (2007) Queen promiscuity lowers disease within honeybee colonies, Proc. R. Soc. Lond. B 274, 67-72.

Sherman P.W., Seeley T.D., Reeve H.K. (1988) Parasites, pathogens, and polyandry in social Hymenoptera, Am. Nat. 131, 602-610.

Shimanuki H., Knox D.A. (2000) Diagnosis of Honey Bee Diseases, US Department of Agriculture, Agriculture Handbook No. AH-690.

Solignac M., Vautrin D., Loiseau A., Mougel F., Baudry E., Estoup A., Garnery L., Haberl M., Cornuet J.M. (2003) Five hundred and fifty microsatellite markers for the study of the honeybee (Apis mellifera L.) genome, Mol. Ecol. Notes 3, 307-311.

Tanaka E.D., Hartfelder K. (2004) The initial stages of oogenesis and their relation to differential fertility in the honey bee (Apis mellifera) castes, Arth. Struct. Dev. 33, 431-442.

Tarpy D.R. (2003) Genetic diversity within honeybee colonies prevents severe infections and promotes colony growth, Proc. R. Soc. Lond. B 270, 99103.

Tarpy D.R., Nielsen D.I. (2002) Sampling error, effective paternity, and estimating the genetic structure of honey bee colonies (Hymenoptera: Apidae), Ann. Entomol. Soc. Am. 95, 513-528.

Tarpy D.R., Page R.E. Jr. (2000) No behavioral control over mating frequency in queen honey bees (Apis mellifera L.): implications for the evolution of extreme polyandry, Am. Nat. 155, 820-827.

Tarpy D.R., Page R.E. Jr. (2002) Sex determination and the evolution of polyandry in honey bees (Apis mellifera), Behav. Ecol. Sociobiol. 52, 143-150.
Tarpy D.R., Nielsen R., Nielsen D.I. (2004) A scientific note on the revised estimates of effective paternity frequency in Apis, Insectes Soc. 51, 203-204.

vanEngelsdorp D., Hayes J., Underwood R.M., Pettis J. (2008) A Survey of honey bee colony losses in the US, fall 2007 to spring 2008, PLoS ONE 4, e6481.

Villa J.D., Danka R.G. (2005) Caste, sex and strain of honey bees (Apis mellifera) affect infestation with tracheal mites (Acarapis woodi), Exp. Appl. Acarol. 37, 157-164.

Walsh P.S., Metzger D.A., Higuchi R. (1991) Chelex ${ }^{\circledR}$ 100 as a medium for simple extraction of DNA for PCR-based typing from forensic material, BioTech. 10, 506-513.

Wang J.L. (2004) Sibship reconstruction from genetic data with typing errors, Genetics 166, 1963-1979.

Weaver N. (1957) Effects of larval age on dimorphic differentiation of the female honey bee, Ann. Entomol. Soc. Am. 50, 283-294.

Webster T.C., Pomper K.W., Hunt G., Thacker E.M., Jones S.C. (2004) Nosema apis infection in worker and queen Apis mellifera, Apidologie 35, 49-54.

Webster T.C., Thacker E.M., Pomper K., Lowe J., Hunt G. (2008) Nosema apis infection in honey bee (Apis mellifera) queens, J. Apic. Res. 47, 53-57.

Williams G.R., Shafer A.B.A., Rogers R.E.L., Shutler D., Stewart D.T. (2008) First detection of Nosema ceranae, a microsporidian parasite of European honey bees (Apis mellifera), in Canada and central USA, J. Invertebr. Pathol. 97, 189-192.

Wilson E.O. (1971) The Insect Societies, Harvard University Press, Cambridge.

Wilson-Rich N., Spivak M., Fefferman N.H., Starks P.T. (2009) Genetic, individual, and group facilitation of disease resistance in insect societies, Annu. Rev. Entomol. 54, 405-423.

Winston M.L. (1987) The Biology of the Honey Bee, Harvard University Press, Cambridge.

Woyke J. (1962) Natural and artificial insemination of queen honeybees, Bee World 43, 21-25.

Woyke J. (1971) Correlations between the age at which honeybee brood was grafted, characteristics of the resultant queens, and results of insemination, J. Apic. Res. 10, 45-55.

Woyke J. (1983) Dynamics of entry of spermatozoa into the spermatheca of instrumentally inseminated queen honeybees, J. Apic. Res. 22, 150-154.

Yang X.L., Cox-Foster D.L. (2005) Impact of an ectoparasite on the immunity and pathology of an invertebrate: evidence for host immunosuppression and viral amplification, Proc. Natl. Acad. Sci. USA 102, 7470-7475. 